\title{
Aplikasi Arsitektur Ekologis Pada Perancangan Balai Besar Pelatihan Pertanian Bawang Merah Di Nganjuk
}

\author{
Ogif Ratuanar ${ }^{1 *}$, Agus Heru ${ }^{2}$, Ana Hardiana ${ }^{3}$ \\ Program Studi Arsitektur, Fakultas Teknik, Universitas Sebelas Maret ${ }^{1}$ \\ ogifratunar@gmail.com* \\ Program Studi Arsitektur, Fakultas Teknik, Universitas Sebelas Maret ${ }^{2}$ \\ Program Studi Arsitektur, Fakultas Teknik, Universitas Sebelas Maret ${ }^{3}$
}

\begin{abstract}
Design of Shallot Agricultural Training Center in Nganjuk starts from the potential of shallot farming with abundant crops. Many of the farmers who want to develop more knowledge about shallot, not just local farmers but also from other regions. This region need a space of agricultural education activities that can accommodate a variety of agricultural training especially in shallot farming,. With the approach of ecological architecture that pay attention to natural factors such as: climate, ecological materials and health of its users. The result of planning with ecological design strategy will result in space of activity which suited to need and environmentally friendly building area
\end{abstract}

Keywords: Trainning center, Shallot, Nganjuk, Ecology

\section{PENDAHULUAN}

Balai Besar Pelatihan Pertanian (BBPP) merupakan lembaga diklat pertanian yang dibawahi oleh Kementrian Pertanian.. Jenis pelatihan yang diselenggarakan dalam balai disesuikan dengan potensi daerah tempat BBPP berdiri. Potensi pertanian Kabupaten Nganjuk adalah bawang merah. Menurut data Dinas Pertanian Kabupaten Nganjuk pada tahun 2012, rata-rata produktivitas tanaman bawang merah sebesar 12,31 ton/ha. Produksi bawang merah tersebut menyumbang $49,23 \%$ produksi bawang merah di Jawa Timur (Julianto, 2013).. Pertanian bawang merah di Nganjuk menjadi acuan bagi daerah lain. Terbukti pada tahun 2016, Dinas Pertanian Kabupaten Nganjuk menerima petani dari Gorontalo dan Papua untuk menerima pelatihan budidaya bawang merah

Balai Besar Pelatihan Pertanian Bawang Merah yang direncanakan merupakan bangunan edukasi berbasis pertanian yang tentunya dekat dengan alam dan akan dapat memanfaatkan potensi alam yang ada seperti halnya pertanian bawang merah yang memanfaatkan kesuburan tanah dan iklim, konsep rancang bangun pun akan mempertimbangkan alam berupa pemanfaatan iklim dan tapak dan memanfaatkan apa yang sudah ada di alam untuk kehidupannya.

Kabupaten Nganjuk yang kaya akan hasil alam memiliki bahan alam yang potensial untuk digunakan sebagai bahan bangunan, seperti tanah liat (dibuat batu bata dan genting) serta bambu. Dengan mempertimbangkan pemanfaatan potensi alam terutama potensi iklim (matahari dan angin) dan bahan lokal maka tepat jika obyek rancang bangun berupa balai pelatihan pertanian bawang merah di Nganjuk menerapkan arsitektur ekologi. Apalagi Nganjuk dikenal dengna kota angin yang memiliki potensi berupa angin yang bertiup kencang. Dengan menerapkan Pendekatan Arsitektur Ekologi pada obyek rancang bangun dapat menciptakan bangunan berwawasan lingkungan dengan strategi perancangan meliputi pemanfaatan potensi lingkungan, pengendlian kendala yang dihadapi di lingkungan, adaptasi iklim 
setempat, efisiensi dan konservasi energi serta pemilihan teknologi yang bijaksana. (Yuliani, 2013).

\section{METODE}

Penelitian tentang penerapan konsep Arsitektur Ekologi pada balai besar pelatihan pertanian bawang merah menggunakan metode sebagai berikut (1) Melakukan identifikasi dan observasi terhadap permasalahan yang ada pada obyek dan lingkungan tapak seperti: kebutuhan ruang dan kegiatan observasi keadaan iklim, eksisting vegetasi dan sirkulasi lingkungan dan juga identifikasi terhadap RTRW kawasan (2) Melakukan identifikasi metode perencanaan yang diperlukan untuk obyek rancang bangun menggunakan aplikasi dari teori teori arsitektur ekologi (3) Merumuskan strategi berbasis ekologi arsitektur yang dapat digunakan untuk merencanakan obyek rancang bangun.

\section{PEMBAHASAN DAN HASIL}

\subsection{Obyek yang Dirancang : Balai Besar Pelatihan Pertanian Bawang Merah}

Merupakan wadah pelatihan pertanian pengembangan sumber daya pertanain. Balai Besar Pelatihan Pertanian utamanya adalah sarana edukasi juga merupakan sarana pemasaran, inovasi, informasi serta inkubator pertanian yang mampu menjadi kekuatan pertanian daerah maupun nasional. Keberadaan balai pertanian menyesuaikan potensi potensi yang ada pada daerah pertanian tertentu.

Seperti halnya Balai Pertanain di Kabupaten Nganjuk, dimana Nganjuk memiliki potensi pertanian bawang merah yang cukup menonjol. Bawang merah menjadi komoditas yang potensial untuk dikembangkan. Edukasi pertanian bawang merah perlu ditingkatkan untuk memperluas wawasan petani petani di daerah. Perencanaan Balai Besar Pelatihan Pertanian Bawang Merah akan sangat relevan dengan kebutuhan wadah edukasi bagi masyarakat.

Namun perlu diketahui bahwa untuk mendukung fungsinya maka diperlukan perumusan kegiatan - kegiatan yang akan dilakukan, baik kegiatan utama maupun kegiatan pendukung.. Menurut PERMEN Pertanian RI NO 120 TH 2014 menyebutkan bahwa diklat terbagi atas diklat teknis dan diklat manajemen. Jenis diklat teknis sendiri terbagi atas (1) pelatihan teknologi produksi/budidaya (2) pelatihan penanganan panen dan pascapanen (3) pelatihan teknologi pengolahan (4) pelatihan pemasaran hasil pertanian. Pelatihan manajemen bertujuan meningkatkan pengetahuan dan kemampuan dalam bidang pengelolaan organisasi, administrasi, pemasaran/tata niaga produk atau peningkatan kesadaran atas norma tertentu, dibagi atas: (1) pelatihan kepemimpinan (2) pelatihan fungsional (3) pelatihan pemberdayaan petani (4) pelatihan manajemen usaha tani. Maka dari jenis pelatihan dapat ditentukan kegiatan kegiatan yang diwadahi dalam balai dan selanjutnya dapat ditentukan ruang ruang yang dibutuhkan.

Selain dari jenis diklat dan kegiatan kebutuhan ruang dalam balai juga dapat ditentukan melalui identifikasi pengguna dalam balai. Pengguna tersebut terdiri atas : pengelola balai, peserta pelatihan, pemateri dan servis. Dari pertimbangan yang disebutkan sebelumnya maka ruang ruang dapat dikelompokkan sesuai dengan peruntukan ruang dan kegiatannya antara lain kelompok ruang penerimaan, ruang pengelolaan, ruang edukasi, penunjang serta kebutuhan ruang servis.

Ruang ruang penerimaan bersifat publik mengakomodasi kegiatan penerimaan di dalam balai. Area pengelolaan balai terdiri atas beberapa ruang disesuaikan dengan kebutuhan pengelolaan, di antaranya: ruang kepala balai, ruang kerja dan ruang rapat. Selanjutnya terdapat area edukasi yang merupakan area paling spesifik dimana ruang-ruang harus mampu mewadahi kegiatan pelatihan secara baik. Ruang edukasi bersifat privat khusus untuk peserta pelatihan dan trainner. Selain kegiatan dan ruang utama juga terdapat fasilitas penunjang seperti sarana menginap, sarana olahraga, klinik, kantin serta koperasi. Sedangkan untuk kebutuhan servis pada keseluruhan dibutuhkan bangunan khusus 
servis yang akan mengakomodasi kebutuhan utilitas seperti kebutuhan listrik dan air.

\subsection{Lingkungan Tapak}

Kabupaten Nganjuk memiliki 20 kecamatan , di antara 20 kecamatan tersebut daerah yang menonjol pertanian bawang merahnya adalah Kecamatan Sukomoro. Kecamatan Sukomoro sendiri selain memiliki produksi komoditas bawang merah yang melimpah juga memilik pasar khusus bawang meah. Kecamatan Sukomoro dalam RTRW Kabupaten Nganjuk tahun 2011 termasuk dalam wilayah pengembangan (A) yakni wilayah yang dikembangkan sebagai pust pemerintahan, pusat perdagangan, pusat fasilitas umum, permukiman dan pertanian, termasuk dalam pusat pelayanan lingkungan (PPL) dimana sangat cocok untuk berdirinya fasilitas pendidikan pertanian

Dengan peruntukkannya sebagai balai pertanian maka eksisting tentunya harus memiliki potensi lingkungan alam yang sesuai dengan peruntukan tapak sebagai balai pertanian. Potensi lingkungan alam yang dimaksud yakni memiliki : sinar matahari yang memadahi dan cocok untuk kegiatan bercocok tanam, potensi air untuk irigasi dan kecukupan untuk aktivitas dalam balai, potensi angin untuk penghawaan alami, potensi tanah untuk mendukung kegiatan berbasis pertanian dalam balai dan yang paling penting tentunya balai tersebut memiliki lokasi yang dekat dengan areal pertanian strategis bawang merah. Dengan posisi tapak yang dekat dengan area pertanian dimaksudkan agar peserta pelatihan dapat belajar langsung mengenai pertanian warga, wirausaha maupun tataniaga bawang merah pada areal strategis bawang merah. Tentunya tapak yang berada di Kecamatan Sukomoro memiliki hal tersebut dan sangat cocok untuk perencanaan obyek BBPP Bawang Merah.

Selain berada di dekat areal strategis pertanian bawang merah juga perlu diperhatikan fasilitas lingkungan yang memadahi dan akses jalan yang mudah dijangkau. Tapak berada di JL Raya Baron, yang merupakan jalan utama dari arah Surabaya menuju Madiun. Akses jalan yang mudah relatif dekat dengan stasiun dan terminal. Letaknya strategis, mudah dijangkau dari arah manapun karena terletak di jalan utama, dilewati oleh kendaraan umun dari arah Surabaya - Jogja, dan Surabaya - Kediri

\subsection{Paradigma Arsitektur Ekologi}

Pembangunan yang berwawasan lingkungan dan holistik dimana memperhatikan hubungan unsur unsur terkait manusia, bangunan dan lingkungan dengan pertimbangan pemanfaatan untuk masa sekarang dan yang akan datang. Pembangunan sebagi proses yang memiliki hubungan kerjasama antara manusia dan alam sekitarnya guna menjaga kelestarian keduanya. Pelaksanaan dan perencanaan Arsitektur Ekologi merupakan penghayatan terhadap pikiran manusia dan alam yang menimbulkan pengamatan analisis terhadap alam yang selanjutnya didukung oleh pengetauan secara teknik dan ilmu pengetahuan yang didapatkan manusia dari budaya dan pengalanan yang menimbulkan kegiatan berdaya cipta dalam perencanaan arsitektur. Beberapa usaha untuk mengerjakan desain dengan kesadaran ekologi seperti desain yang hijau dan berkelanjutan, setiap keputusan desain harus dalam rangka perbaikan, pembaruan dan berkontribusi untuk kehidupan sosial, ekonomi dan lingkungan yang penting untuk setiap individu maupun komunitas .(Berkebille, 1996).

Pada hakikatnya Arsitektur Ekologis mengandung bagian bagian dari arsitektur biologis (arsitektur kemanusiaan yang memperhatikan kesehatan), arsitektur alternatif, arsitektur matahari (dengan memanfaatkan energi surya), arsitektur bionik (teknik sipil dan konstruksi yang memperhatikan kesehatan manusia serta biologi pembangunan). Maka istilah Eko Arsitektur adalah istilah holistik yang sangat luas dan mengandung semua bidang. Prinsip bangunan ekologis antara lain: (1)Penyesuaian terhadap lingkungan yakni bangunan BBPP Bawang Merah yang dirancang menyesuaikan lingkungan tempatnya akan dibangun baik penyesuaian terhadap iklim, topografi, struktur tanah, lingkungna air dsb (2) Menghemat penggunaan energi yang tidak dapat diperbarui, mengedepankan strategi penghematan energi dengan memanfaatkan sumber daya alam yang ada seperti cahaya 
matahari, angin dan air. (3) Pemeliharaan terhadap sumber daya alam yang ada dan menjaga kelestariannya (udara, tanah, air),(4) Memanfaatkan dan menggunakan sumber daya alam sekitar pada kawasan perencanaan untuk sistem bangunan, baik yang berkaitan dengan material bangunan maupun untuk utilitas bangunan (sumber energi, penyediaan air) (Frick, 2007)

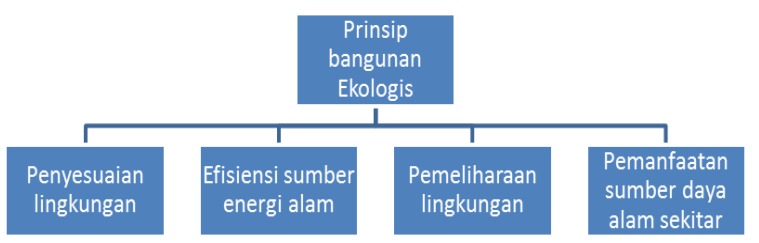

Gambar 1 Prinsip Bangunan Ekologi

Sumber: Frick, 2007

Sedangkan kriteria banguanan sehat dan ekologis berdasarkan buku Arsitektur Ekologis versi Heinz Frick, antara lain :

- Menciptakan kawasan hijau di antara kawasan bangunan.

- Memilih tapak bangunana yang sesuai dengna peruntukan obyek yang dirancang.

- Menggunakan bahan bangunan buatan lokal.

- Menggunakan ventilasi alam dalam bangunan.

- Memilih lapisan permukaan dinding dan langit-langit ruang yang mampu mengalirkan uap air.

- Menjamin bahwa bangunan tidak menimbulkan permasalahan lingkungan

- Menggunakan energi terbarukan.

\subsection{Pemanfaatan Iklim}

Iklim dapat disiasati sehingga dapat dimanfaatkan secara optimal sesuai dengan perinsip Arsitektur Ekologis. Strategi penaganan iklim yang sesuai antara lain: Pengoptimalan cahaya matahari sebagai sumber pencahayaan utama. matahari, maka strategi yang dapat digunakan antara lain melalui program ruang, penempatan ruang fungsional di arah utara selatan agar ruang tidak terlalu terpapar sinar matahari dan runag akan lebih sejuk. Selain menentukan orientasi penanganan radiasi matahari pada balai juga memanfaatkan Pemanfaatan tanaman peneduh

pada kawasan agar terasa sejuk terutama pada area timur dan barat

Peneduhan menjadi solusi paling tepat untuk meminimalkan silau matahari, dimana pada tapak matahari bersinar terik sepanjang tahun. Peneduhan dapat dilakukan dengan membuat overhang maupun strategi penanaman vegetasi. Isolasi radiasi panas juga dapat digunakan dengan menggunakan ruang udara panas, prinsipnya hampir sama dengan penataan program ruang, ruang panas ini diletakkan pada atas ruang fungsional. Ruang panas tersebut berupa atap yang dapat menangkap udara panas yang terpancar.

Selain cahaya matahari faktor angin juga menjadi pertimbangan dalam BBPP Bawang Merah. Penentuan arah angin yang dapat menentkan penempatan bukaan dan konfigurasi massa sehingga sirkulasi udara lancar. Penataan orientasi bangunan diletakkan antara lintasan matahari dan angin. Letak gedung yang paling menguntungkan apabila memilih arah dari timur ke barat. Bukaanbukaan yang lebar menghadap Selatan dan Utara agar tidak terpapar langsung sinar matahari. Strategi ventilasi silang diberlakukan agar sirkulasi udara dalam ruang BBPP lancar. Penempatan rasio bukaan yang seimbang, maksudnya adalah agar aliran udara dapat seimbang antara yang keluar dan masuk sehingga udara dapat berganti (cross ventilation). Bukaan bukaan bukan hanya terdapat pada jendela tapi juga melalui .lubang udara loster. Penempatan bukaan bukaan pada dinding bangunan sesuai dengan arah angin dan beberapa ruang dibuat terbuka agar sirkulasi udara lancar.

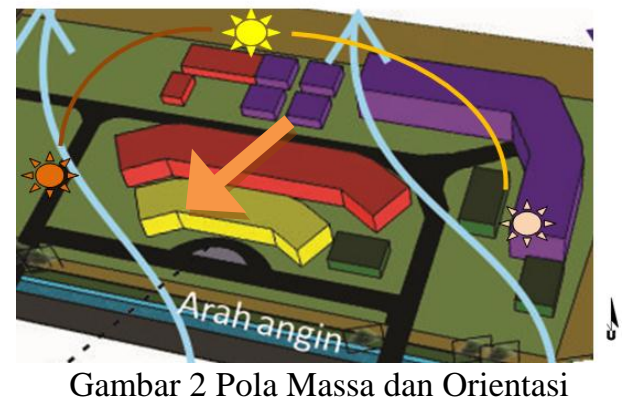


Konfigurasi bangunan untuk jalan angin, jarak pada bangunan menjadi penting untuk sirkulasi pada tapak. Dari pengamatan pada tapak angin berhembus dari selatan ke utara, kecepatan rata rata angin $1,03 \mathrm{~m} / \mathrm{s}$. Pada saat musim kemarau potensi angin sangat besar mencapai $2,57 \mathrm{~m} / \mathrm{s}$. Keadaan angin yang cukup kencang perlu strategi khusus agar angin ini dapat dimanfaatkan sebagai pengkondisian udara dan sirkulasi udara lancar pada tapak.

\subsection{Sirkulasi pada Tapak}

Sirkulasi pada tapak harus ramah pada keberadaan pejalan kaki dan terdapat unsur penghijauan pada tapak serta memiliki peruntukan yang jelas. Jalan sirkulasi dibagi atas 3 jalur yakni: sirkulasi untuk penerimaan, sirkulasi menyeluruh kawasan, dan sirkulasi jalan untuk bagian servis

- Sirkulasi area penerimaan terdapat pada sebelah selatan tapak dengan membedakan jalur masuk dan jalur keluar kendaraan agar sirkulasi lebih kondusif . selain itu pada sirkulasi penerimaan memiiliki dua arah jalan untuk memudahkan sirkulasi. Jalan dua arah hanya diletakkan di area depan balai. Jalan dibuat mengelilingi balai dan melewati seluruh area agar akomodasi dari satu area ke area lain lebih mudah dan terkoneksi.

- Terdapat area drop off pada area penerimaan untuk menururnkan penumpang

- Pada setiap area terdapat trotoar dengan jalur hijau untuk sirkulasi pejalan kaki

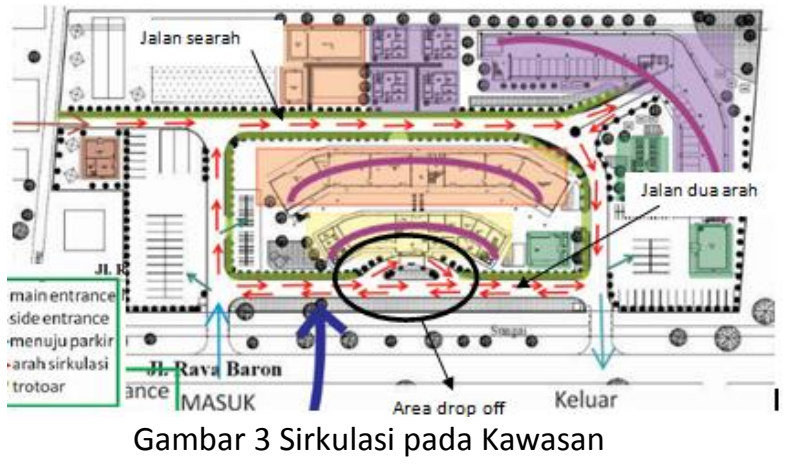

\subsection{Lansekap dan Vegetasi}

Keberadaan vegetasi merupakan hal yang penting untuk penghijauan kawasan, penting untuk menemuka tata lansekap yang padu terhadap obyek rancang bangun dan vegetasi yang sesuai dengan menggunakan tanaman peneduh sesuai dengan kebutuhan pada tapak, tanaman pengarah pada jalan dalam balai, ground cover alami pada taman taman dan paving pada area tertentu seperti area parkir, tanaman estetis dipakai untuk taman mempercantik lansekap pada balai, Penggunaan paving berongga sehingga air tetap bisa masuk ke dalam tanah, Penggunaan rain garden sebagai strategi pelestarian air, diletakkan pada daerah daerah limpasan hujan.

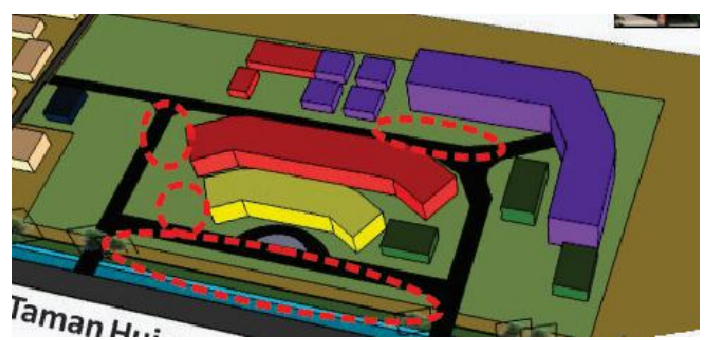

Gambar 4Titik Penempatan Rain Garden

\subsection{Struktur dan Material}

Mendapatkan struktur bangunan yang kuat menopang beban serta penggunaan material yang sesuai dan ramah lingkungan merupakan salah satu penerapan dari arsitektur ekologi. Dimana struktur harus mamapu, menahan beban dan perlindungna terhadap gaya dan iklim ygn bekerja seperti angin, hujan, panas dan dingin, pengerjaannya mudah , mampu mendukung ekspresi tampilan bangunan serta menggunakan material lokal yang mudah didapat.

Super structure yang akan digunakan adalah struktur atap baja untuk struktur atap bangunan utama (bangunan pengelola, edukasi dan asrama), sedangkan untuk banguan lain yang lebih kecil menggunakan struktur baja ringan. Struktur baja dipilih kareana memiliki kekuatan yang baik, masa pakai panjang, sedangkan baja ringan dipilih karena bahan mudah didapatkan serta harganya yang murah. Plat beton untukdak lantai bertingkat dan overhang. Untuk penutup atap akan digunkan genteng tanah liat kareana sumber daya tanah liat melimpah pada sekitar tapak. 
Untuk Sub structure digunakan pondasi kombinasi foot plate dan batu kali maupun tinag pancang.

- Kombinasi struktur pondasi foot plate dan batu kali akan digunakan pada bangunan dengan tinggi 2 lantai..

- Struktur batu kali akan digunakan pada bangunan bertingkat satu

- Struktur tiang pancang digunakan untuk banguna 4 lantai pada balai

Sistem upper structure menggunakan beton, bertulang dimana memiliki waktu pakai yang lama, tahan panas, proses pengerjaan cepat. Sedangkan untuk elemen pengisi struktur pada dinding digunakan dinding bata dan loster, dimaana lingkungna pada sekitarnya merupakan penghasil material tersebut selain itu umur pemakaiannya panjang dan mudah mendapatkannya, elemen kaca juga digunakan sebagai strategi memasukkan cahaya dalam ruang. Untuk lantai digunakan keramai agar mudah dibersihkan dan relatif mudah mendapatkan barang di pasaran serta pilihan warna yang beragam. Sedangkan untuk plafond dipilih plafond bambu karena merupakan bahan material lokal yang ramah lingkungan.
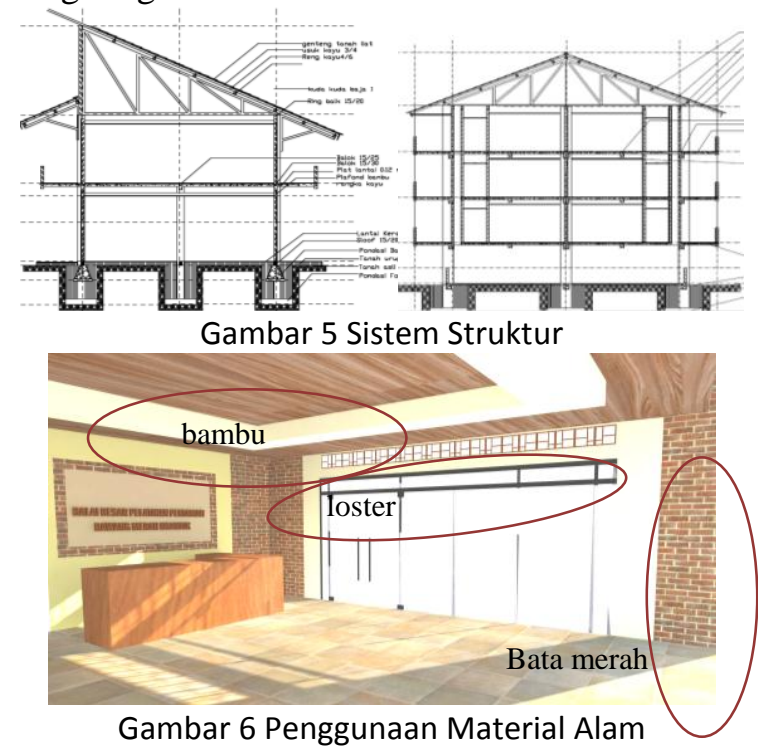

\subsection{Utilitas Banguan Ekologis}

Menentukan utilitas pada obyek, dimana dapat diterapkan strategi strategi ekologis yang ramah lingkungan terhadap obyek rancang bangun yang ramah terhadap lingkungan, sesuai kebutuhan serta pengaplikasian dan perawatan yang mudah. Dimana yang akan dibahas terutma adalah mengenai strategi listrik ramah lingkungan dan pengelolaan air.

Listrik merupakan kebutuhan guna menunjang fasilitas pada bangunan. Energi listrik dapat dihasilkan dari potensi alam sekitar. Pada tapak terdapat potensi alam berupa matahari yang bersinar sepanjang tahun dan angin yang memiliki kecepatan angin 2,75 termasuk dalam kategori 3 dalam kecepatan angin . Matahari dan angin ini dapat dikonversi dengna pengaplikasian instalasi solar sell dan turbin angin, kombinasi dari kedua pembangkit ini dinamakan pembangkit listrik tenaga hybrid yang ramah lingkungan.

Air bekas merupakan air sisa yang berasal dari aktivitas mandi, cuci tangan atau wudhu. Air bekas tersebut masih bisa digunakan dengan menggunakan metode penyaringan dengan menggunakan eceng gondok, air yang sudah disaring dapat digunakan kembali.

Selain pengolahan air bekas air hujan juga diolah dengan metode pemanenan air hujan merupakan salah satu strategi untuk menghemat air. Selain itu air hujan yang tak tempat ditampung dapat meresap dan mengisi air tanah, dengan menggunakan biopori maka akan lebih optimal penyerapannya dan dapat juga menghasilkan pupuk kompos. Sampah organik dapat dimanfaatkan lagi menjadi pupuk dengan komposter.

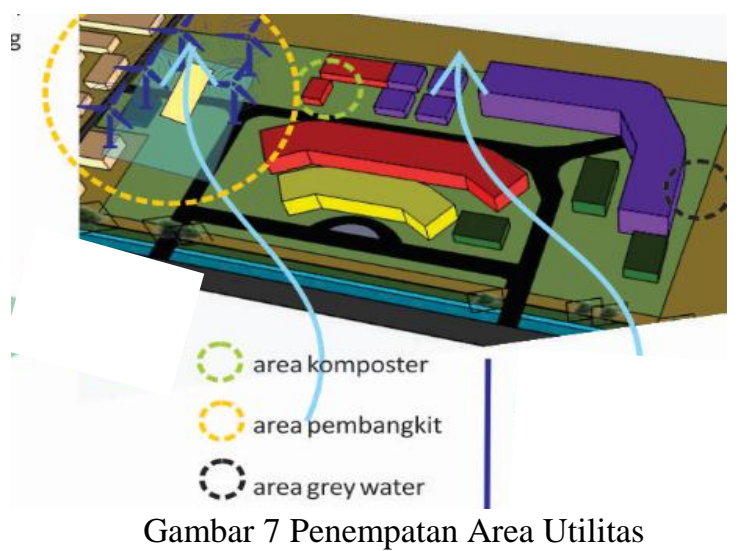

Gambar 7 Penempatan Area Utilitas 


\section{KESIMPULAN}

Pada perencanaan Balai Besar Pelatihan Pertanian (BBPP) Bawang Merah pengaplikasian Arsitektur Ekologis yang ramah lingkungan diwujudkan dengan memperhatikan kondisi fisik tapak yakni iklim, tanah maupun air. Perencanaan obyek sudah sesuai dengan RTRW Kabupaten Nganjuk dan mengambil tapak dekat dengan area strategis pertianian bawang merah, mengingat fungsi balai sebagai wadah edukasi pertanian bawang merah. Potensi pada tapak dioptimalkan pada perencanaan seperti potensi iklim matahari dan angin yang dimanfaatkan untuk pencahayaan dan penghawaan alami melalui strategi khusus seperti: strategi peneduhan bangunan dengan overhang maupun vegetasi, penempatan bukaan yang mempertimbangkan arah angin, orientasi dan dan penataan massa yang sesuai. Konfigurasi massa juga mempertimbangkan sirkulasi pada tapak sehingga sirkulasi dapat mengakomodasi aktivitas dari area satu menuju area lain, sirkulasi pejalan kaki juga terdapat pada tapak disertai dengan penghijuan di sepanjang jalan sirkulasi, selain jalur hijau juga terdapat taman taman yang memiliki fungsi sebagai taman limpasan hujan (rain garden). Aplikasi Arsitektur Ekologis juga muncul dalam pertimbangan pemilihan banhan bangunan yang ekologis, pada balai bahan bangunannya merupakan bahan yang mudah ditemukan dan ada di lingkungna sekitar seperti batu bata, loster, genting dan bambu. Utilitas listrik dan air juga tak lepas dari aspek ramah lingkungan, energi listrik didapatkan dari pembangkit listrik tenaga hybrid (tenaga matahari dan angin) sedangkan untuk utilitas air menerapkan pengolahan air bekas pemanenan air hujan dan pengolahan sampah menggunakan komposter serta biopori.

\section{REFERENSI}

Berkebille, R. (1996). In L. C. Zeiher, The Ecology of Architecture. New York: Whitney Library of Design .

Frick, H. (2007). Dasar Dasar Arsitektur Ekologis. Yogyakarta: Penerbit Kanisius.

Julianto. (2013). Kajian Perbedaan Perilaku Budidaya Petani Terhadap Capaian Produktivitas Bawang Merah di Desa
Selorejo dan Desa Bagor Kulon Kecamatan Bagor Kabupaten Nganjuk . 2.

PERMEN Pertanian RI NO 120 TH 2014

Yuliani, S. (2013). Metoda perancangan Arsitektur Ekologi. Surakarta: UPT. Penerbitan dan Percetakan UNS. 